\title{
INVERTEBRATE FAUNA OF THE INTERTIDAL ZONE OF THE TOKARA ISLANDS -I. INTRODUCTORY NOTES, WITH THE OUTLINE OF THE SHORE AND THE FAUNA-
}

\author{
AUTHOR(S): \\ Tokioka, Takasi
}

\section{CITATION:}

Tokioka, Takasi. INVERTEBRATE FAUNA OF THE INTERTIDAL ZONE OF THE TOKARA ISLANDS -I. INTRODUCTORY NOTES, WITH THE OUTLINE OF THE SHORE AND THE

FAUNA-. PUBLICATIONS OF THE SETO MARINE BIOLOGICAL LABORATORY 1953, 3(2): 123 138

\section{ISSUE DATE:}

1953-12-20

URL:

http://hdl.handle.net/2433/174478

RIGHT: 


\title{
INVERTEBRATE FAUNA OF THE INTERTIDAL ZONE OF THE TOKARA ISLANDS \\ I. INTRODUCTORY NOTES, WITH THE OUTLINE OF THE SHORE AND THE FAUNA ${ }^{\left.1)_{2}\right)}$
}

\author{
TAKASI TOKIOKA
}

Seto Marine Biological Laboratory, Sirahama

With Plates IV-VI and 6 Text-figures

A scientific research party, associated under the management of Mr. Yoshitaka TsuTsu, director of the Osaka City Museum of Natural History, visited the Tokara Islands and undertook careful researches in each special field of sciences during the period from June 26 to July 12 of 1953 . The Tokara Islands consists of 10 small islands stretching in a series between the southern end of Kyûsyû and Okinawa, just in the range from $29^{\circ}$ to $30^{\circ} \mathrm{N}$. (Fig. 1), and is of special interest to biologists of this country by the fact that the northern limit of the distribution of some tropical animals and plants and the southern limit of the distribution of some boreal animals and plants are found in or near these islands. However, no comprehensive biological survey has previously been carried out there.

Fortunately I had an opportunity to join this party and engaged myself in collecting and studying the invertebrate animals in the intertidal zone of the Islands. The biological party first visited Takarazima (Pennell or Roy Island), the southern-most one of this islands group, and then Nakanosima (Pinnacle Island) which is the largest main island and is situated near the northern end of the group. Thus, we may be able to make a comparison between the faunae and florae of northern and southern ends of the Islands.

As our sojourn on each island was limited to 7-10 days, I was not able to extend the scope of the observation and collection below the low water mark. Thus, the survey was confined to the invertebrate animals excepting insects inhabiting in the intertidal zone, in small or shallow tide pools or under stones in pools. At Takarazima,

1) Scientific Survey of the Tokara Islands, Report No. 2.

2) Contributions from the Seto Marine Biological Laboratory, No. 208.

Publ. Seto Mar. Biol. Lab., III (2), 1953. (Article 9) 


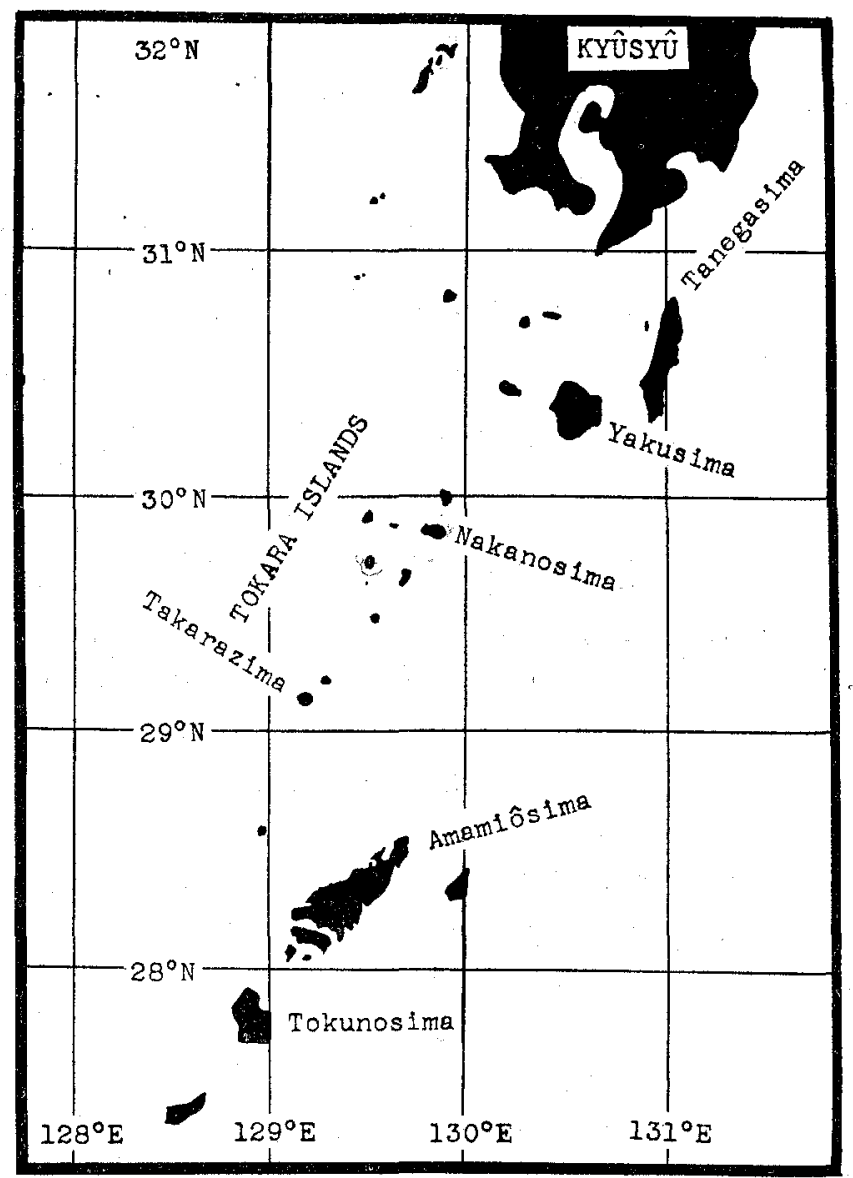

Fig. 1. Map of the Tokara Islands.

I could explore along nearly all the coast of the island and succeeded to obtain some satisfactory results. At Nakanosima, however, the fringing reef or the low-water abrasion bench is not so developed as in Takarazima, except for a part of the southern coast; the coast is steeply cliffed at many places and refuses our approach. Moreover, a heavy weather in the beginning of the rainy season prevented much our active works. Thus, I could observe and collect the animals only at several stations; the fauna and flora of the whole island remains almost unexplored. For these reasons, I prefer to note at first on the invertebrate fauna on the reef of Takarazima and then make mention of that of Nakanosima, comparing it with that of Takarazima.

Besides my own collection, many precious specimens were offered me by other members of the party. Many peoples of the islands helped us much in collecting the material. The specimens, thus gathered, were classified and some of them were already 
sent to specialists for identification and preparing the lists and informations which will be published in reports of this series.

The invertebrate fauna of the coral reef of these islands, as might be expected, is of tropical nature. It is, however, too ambitious to consider the fauna reported here as invariable. Seasonal change of climate and the periodicity of the breeding season in some animals are naturally expected in this region. Consequently, I hope that the intertidal fauna of these islands, preliminarily reported here, may be accepted merely as a phase in the annual succession.

\section{General Feature of the Invertebrate Fauna on the Coral Reef of Takarazima}

Along the whole $12 \mathrm{~km}$ long coast around the island, the raised fringing coral reef is exposed at low tide (Fig. 2). The reef is about $100 \mathrm{~m}$ broad and built entirely with dead and dark-coloured corals. The island itself is a raised reef, about $300 \mathrm{~m}$ at the highest point and bordered with a plane meadow, the seaward edge of which is quite rocky and so rugged that it is very hard to walk upon. The high water mark

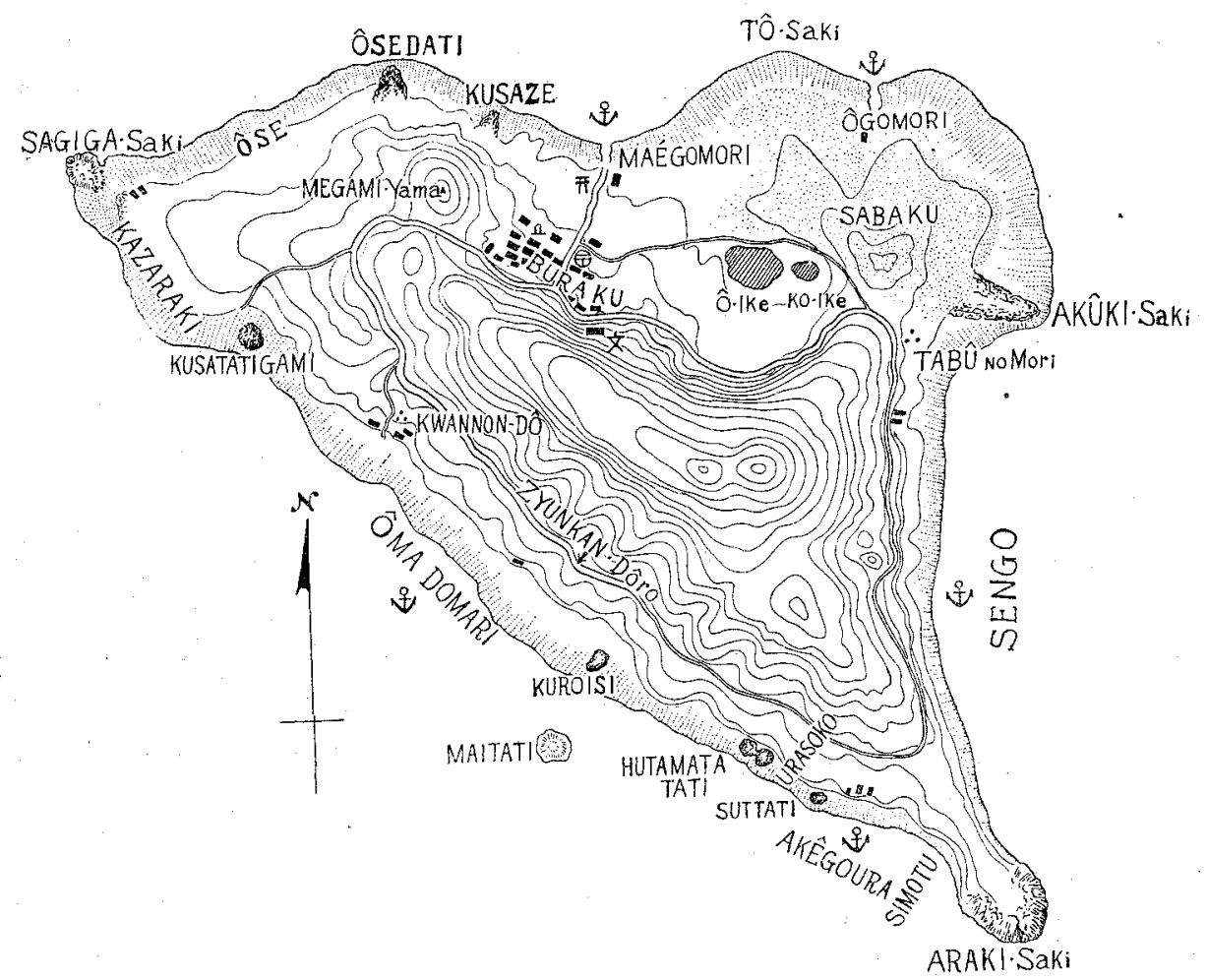

Fig. 2. Map of Takarazima. 
is discerned here. The surface of the reef becomes gradually even to the seaward edge of the reef till it forms at last a wide flat where many boat channels are running in from the margin of the reef. The larger channels which allow the passage of native boats are called "Komori" (komoru=to harbour in Japanese), while the smaller channels are named "Yato" by inhabitants. The bottom of narrow Yato is considerably widened, eroding the reef and forms the caves under the water. There are many pools of various sizes and depths on the reef. The most strange arrangement of pools is found at the south-eastern part of the island, where many shallow pools are arranged as the paddy fields in this country.

When the exposed reef at low tide is viewed from the height, it will be clearly seen that the reef can be divided into the following four zones in respect to the colouration. They are the grayish zone along the high water mark, the yellowish zone below the precedence and next the purplish zone, followed by the brownish zone which fringes the seaward edge of the reef (P1. IV). This division seems to be of a general character applicable to all around the island. The brownish zone may come deeply into the reef along the Yato and Komori. In several places, the sandy beach is formed above the grayish zone. Especially it is developed remarkably at the north-east part of the island and called "Sabaku" which means the desert in Japanese; here is a thicket of Pandanus tectorius Solandex. The sands consist chiefly of coral sands mingled with a small amount of tiny shell fragments and foraminiferan shells Baculogypsina (Fig. 6) and Orbitolites. In the following, the general character of the fauna in each zone is described briefly.

\section{Beach area above the grayish zone.}

The land hermit crabs, Coenobita spp., are the commonest inhabitants in and near the thicket of Pandanus. A species of land crab with purplish chelae, Geograpsus lividus stormi $\mathrm{DE}$ MAN, is found frequently near the thicket and lodging in holes in the sandy banks. Tylos granulatus MiERs is buried in sand and a few individuals of Orchestia spp. are often met with under the stranded sea-weeds and dusts. Many shallow pools are scattered in the meadow near the grayish zone, holding the fresh water in the surface layer and the brackish water in the bottom. Aëdes larvae and tadpoles of Polypedates japonicus (HALLOWELL) are found commonly in these pools and a species of harpacticid copepod, Tigriopus japonicus MORI and some amphipods are also discovered in some of these pools.

\section{Grayish zone.}

The colour of this zone seems to be the natural hue of dead corals. A conspicuous littorinid-zone can be discriminated in the upper part commonly wetted by the sprays of waves. This zone is characterized by the dense population of the single species, 
Tectarius (Nodilittorina) vilis (MENKE), although I found only three individuals of Tectarius (Nodilittorina) granularis GRAY in this zone at Akûki Saki and an individual of Littoraria pintado (Wood). On the east side of Sagiga Saki, Melarhaphe (Littorinopsis) obesa (SowERBY) is found here and there above the littorinid-zone. This smart littorinjd, faintly coloured violet, could also be found rarely on the southern coast at Ôse and Akêgora. Below the littorinid-zone, the Chthamalus-Siphonaria-zone is discernible. The barnacle is represented by the single species, Chthamalus intertextus DARWIN which has the shell coloured internally violet. Siphonarians observed here belong to a single species, S. rucuana PILsBry. Ostrea (Lopha) cucullata BorN is found sparsely between the Chthamalus-Siphonaria-zone and the upper part of the following yellowish zone.

Near Ma'́gomori, a large Komori near the middle of the northern coast, the grayish zone slopes sharply and in many places is represented by the surface of the cliff, the lower part of which is evidently in the yellowish zone. Here many small neritid snails, Nerita (Ritena) plicata LINNÉ, Nerita (Ritena) helicinoides laevilabris PILSBRY, Nerita (Ritena) undata striata BURRow and Nerita (Amphinerita) polita LinNÉ, are attached to the surface. Numerous rock-slater, Megaligia exotica (Roux), are running around the wide range from the area above the high water mark to the yellowish zone. A large muddy coloured crab, Geograpsus crinipes (DANA), may be found near the high water mark.

\section{Yellowish zone.}

This zone merges completely under the water at high tide; its yellowish colouration is probably attributable to the presence of some lower algae on the surface of the reef. The surface is somewhat rugged in places, but as a whole considerably smoothed as compared with the grayish zone. Tide pools are exposed here and there at low tide. At the time of our visit, many small Ulvaceae chiefly consisting of Ulva conglobata KJELIMAN were growing widely in this zone. The most remarkable sedentary animal is Tetraclita squamosa which contains the reddish subspecies formosana Hiro and the greenish subspecies viridis DARWIN. Near Hutamatatati on the south-eastern coast and Akt̂kj Saki, a great many individuals of small blackish cerithiids are found in shallow pools in the upper part of this zone; their empty shells are stranded numerously upon the grayish zone. Muricid snails, Drupa (Morulina) granulata (Duclos) and Thais (Mancinella) distignuenda (DUNKER \& ZELEBOR) appear in the lower part. The fauna in pools in the yellowish zone is very poor, only some gobiid and blenniid fishes are the common inhabitants. In deeper pools, however, we can hear the crack of a squill, Gonodactylus chiragra FABRICIUS. I must confess here that I am also one of the sufferers who have get an enormous mitten of this animal on the glass vessel. The wall of the glass tube was finely punched at a blow. On the undersurface of 


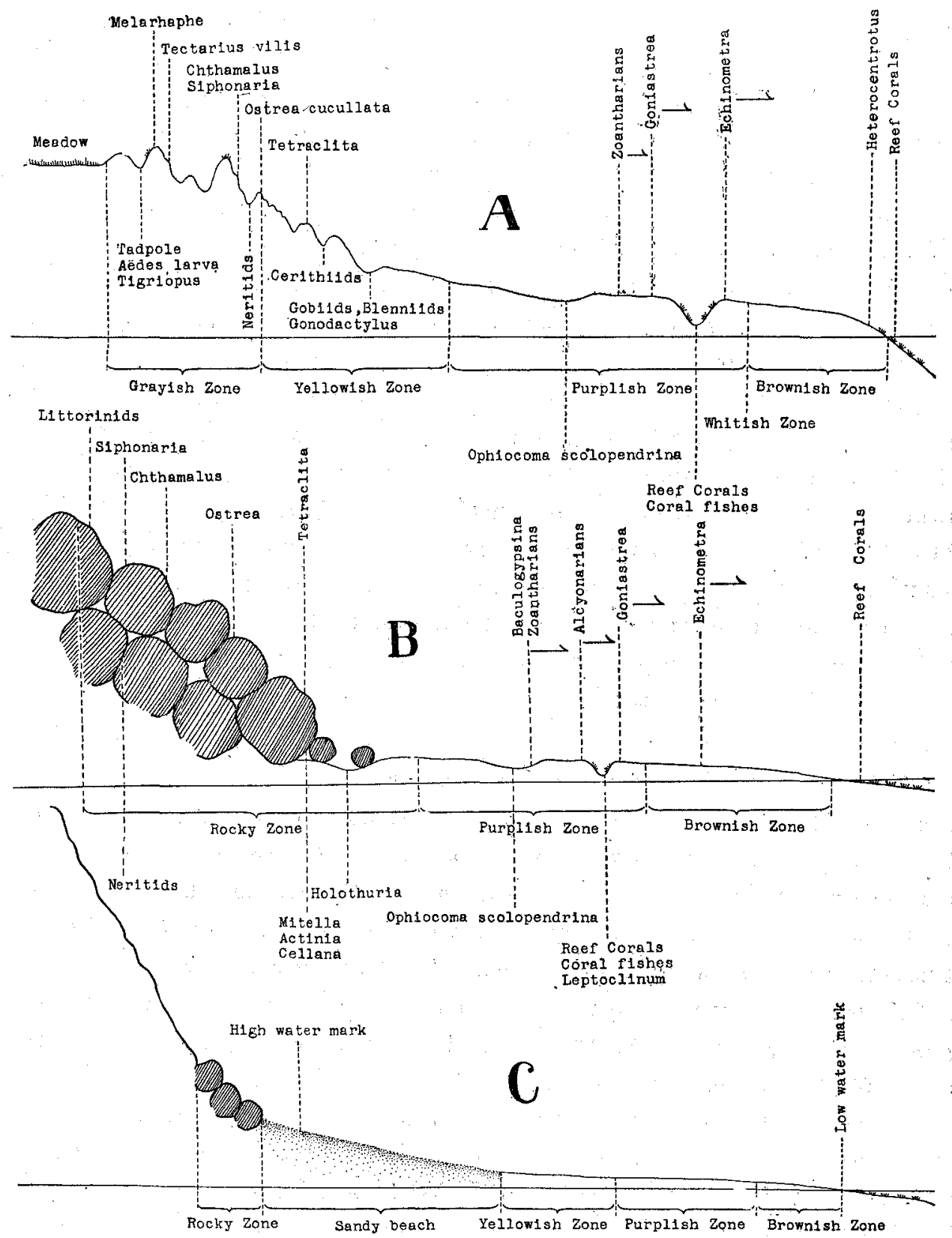

Fig. 3. Schemata of optical sections of the shore of Takarazima (A), shore of the western coast of Nakanosima (B) and that of the eastern coast of the same island (C). 
stones in deep pools, we can see isognomonid bivalves, sponges, ascidians-Ascidia aperta SLUITER and whitish didemnids, small chiton Ischnochiton comptus (GoulD) and small isopods like Sphaeroma, etc. Ascidia aperta varies conspicuously in colour from colourless transparent to reddish orange. Besides, the following tiny snails: Bothropoma? granulosum (PEAsE), Philbertia chichijimana PllsBry var., Planaxis (Angiola) viratus SMITH and Pyrene (Zatra) sinensis (SowERBY) are found commonly under stones. A large crab running rapidly on the reef is Grapsus strigosus HERBST, edible and most useful as bait in this island:

Purplish zone.

The surface of the reef becomes in this zone quite even and is covered by a species of Melobesiae, Porotithon sp. which colours the surface gray purplish. Slight depressions retaining moisture during the ebb tide are crowded with colonies of grayish Zoanthus sp., the oral disc of which is expanded in the water and shows a pretty pinkish or greenish striations. Other zoantharians such as Palythoa spp. and Isaurus sp. appear along the margin of pools or Yato. There are found two distinct species in Palythoa; one is provided with a well-developed coenenchyme and at a glance reminds us of a species of astraeid corals, while the other has extremely thin coenenchyme and resembles the common Zoanthus. The former is whitish yellow or yellowish brown in colour when exposed, but in the water it changes to reddish brown by the expansion of the oral disc. The latter is brownish externally and dark greenish on the oral disc. Isaurus shows a wide range of variations in colour, greenish to brownish, and in size of tubercles; some specimens are nearly devoid of these knobs. All these zoantharians together with some alcyonarians known usually as "soft corals" are called "Naba" by inhabitants, which means the mushroom in some districts of Japan. A species of reef corals, Goniastrea aspera VERRILL may be seen commonly mingled with these Naba. In addition, the following nine corals may be exposed along the margin of deep pools, Yato and Komori and on the slope along the reef margin at low tide.

Porites cf. haddoni VAUGHAN

Acropora abrotanoides (LAMARCK)

Acropora (? abrotanoides var.)

Acropora pectinata (BRook)

Acropora (Tylopora) scherzeriana (BRüGGEMANN)

Psammocora gonagra KLUNZINGER

Coeloseris mayeri VAUGHAN

Pocillopora verrucosa (ELLIS \& SOLANDER)?

Pocillopora damicornis (LINNÉ) 
In the lower part of this zone, a narrow whitish zone marked by a white Porolithon sp. can be discerned at several stations, although the distinction is possible rather with some difficulties. When we break the surface of the reef near the whitish zone, we can find under the thin layer of the purplish Porolithon many nest tubes of a sedentary: polychaete, Pomatoleios crosslandi PIXELL, and nưmerous sipunculids, such as Phascolosoma albolineatum (BAIRD), boring below the nest tubes of Pomatoleios. This sipunculid often extrudes its proboscis which is marked conspicuously with white and reddish brown-dark brown bands out of the hole under the strong sun-shine at ebb tide. Abundant brittle stars, Ophiocoma scolopendrina (LAMARCK), Holothuria (Holothuria) atra JAEGER covered with sand grains over the body surface and Holothuria (Holothuria) vagabunda SELENKA without sandy coat appear in shallow pools in this zone. Several species of Polyclada are also met with frequently near the shallow pools.
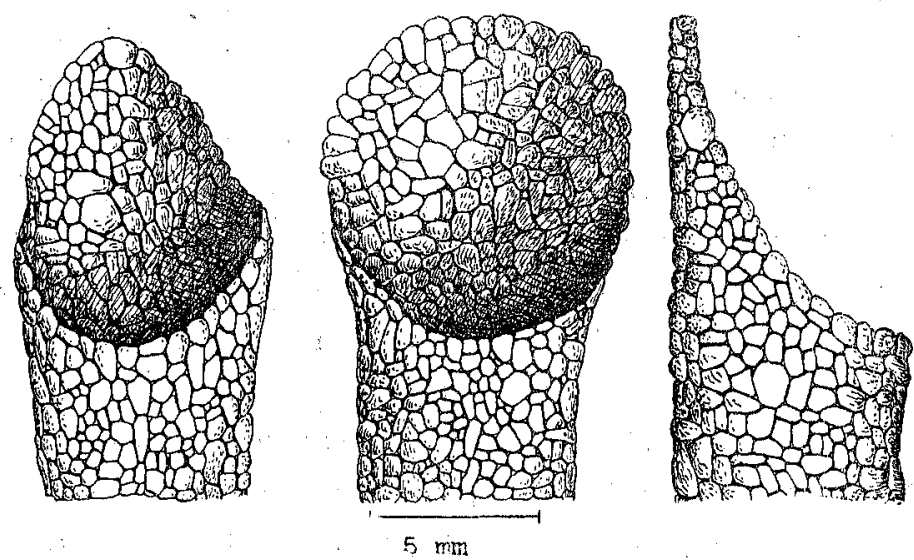

Fig. 4. Opening of the nest tube of Idanthyrsus pennatus (PETERS). The left two viewed from below, the right one shows the lateral side.

Next comes the turn to look in large and deep pools and Yato. The wall is beautifully painted with sea-weeds, green by Halimeda, Caulerpa, Dictyosphaera, Valonia and Chlorodesmis, grayish violet by Mastophora and Liagora and red-scarlet by Cheilosporum, Galaxaura and some species of Melobesiae. The sponges add yellow, violet, red and black to this colouration and some compound ascidians, Leptoclinum and Didemnum, harbouring zoochlorellae in lacunae of the colony, add bluish green-whitish green. Small but very pretty violet hydrocoral, Distichopora violacea (PALLAs) may be found among these algae and animals. Ophiomastix anmulosa (LAMARCK), larger than Ophiocoma scolopendrina and coloured grayish on the aboral and reddish orange on the oral side, may be commonly found in these pools. Several individuals 
of a tropical sea anemone, Thalassianthus aster. LEUCKART was found in the cleft of the reef near Ôse. Scarlet Dendrophyllia decorates the walls of narrow and dark Yato or clefts of pools. Many reef corals varying in colours and shapes are growing in the water and various coral fishes are swimming among them like butterflies.

There are many pot-like small depressions on the reef, in which we can find the openings of the nest tubes of a sedentary polychaete Idanthyrsus pennatus (PETERs) (Fig. 4), reddish orange Ascidia aperta and yellowish orange sponge, Tethya. sp. Many of minute crabs, Pachygrapsus minutus A. M. EDWARDS are running around there for searching food; Eriphia laevimana LATREILLE with red eyes and E. scabricula. DANA are also the common crabs in this region.

Gastropods found here are all of tropical nature; important species are listed below :

Muricidae:

Drupa morum RöDing

Drupa albolabris (BLAINVILLE)

Drupa ricina (LINNÉ)

Buccinidae :

Engina mendicaria (LINNÉ)

Mitridae :

Mitra (Strigatella) virgata (REEVE)

Mitra (Strigatella) litterata (LAMARCK)

Mitra (Strigatella) decurtata (REEvE)

Conidae:

Conus (Virroconus) ebraeus LINNÉ

Drupa morum, the most remarkable muricid with violet aperture, was rather rare in the range between Maégomori and Tô Saki. Thais (Mancinella) armigera (DILLWYN) is said to climb up the wall of Yato at low tide. Most of hermit crabs found in this zone are coloured brightly. Most impressive animal near the whitish zone is a species of phyllodocid polychaete, which is extremely slender reaching ca. $700 \mathrm{~mm}$ in length and creeping actively when the water washes this zone.

\section{Brownish zone.}

The purplish zone is altered to the brownish zone by the vegetation grown on its surface. This vegetation consists of small Gelidiaceae and their youngs and other Rhodophyceae such as Hypnea, Dictyocha etc. and forms a sort of mat covering this area. Large disc-shaped foraminiferan Orbitolites complanata LAMARCK is found commonly attached to these small algae. The fauna of this zone is nearly the same as in the preceding zone excepting the increase of small pocket-like depressions, in which 
always one elliptical sea urchin, Echinometra mathaei (Blainville), can be found. It is a noteworthy fact that darkly coloured individuals of Echinometra mathaei are found much more frequently than whitish individuals near the reef edge, while the former is much fewer than the latter in the part distant from the reef edge. The slope along the reef margin is covered by various reef corals, among which we can find some soft corals, Lobophytum, Microspicularia, etc., and Heterocentrotus mammillatus (LINNÉ); the last-named urchin is familiar to the inhabitants of the island by its thick pipe-like spines and distributed in the range between Maégomori and Tô Saki. Microspicularia catches our eyes by its rapid change of colour which is brownish in the water, while passes immediately into white when exposed.

Sandy zone.

There are several narrow sandy zones which merge under the water at high tide. Besides, some pocket zones in the reef keep a considerable amount of sand in them. Ocypoda sp. is a sole crab inhabiting in the upper part of the sandy zone. Asaphis dichotoma (ANTON), Venus (Periglypta) reticulata LINNÉ and Arcopagia (Scutarcopagia) scobinata (LINNE) are the bivalves found in sandy zones. A considerable number of Siphonosoma cumanense (KEFERSTEIN), one specimen of Ochetostoma erythrogrammon LEUCKART \& RÜPPELL and an individual of small and yellow enteropneust were collected from the sandy zone of this island.

The zonation mentioned above is shown schematically in Fig. $3 \mathrm{~A}$. At first, I was rather disappointed when I reached to the reef and surveyed the grayish-yellowish zones where the surface of the reef was rather bare and the fauna was very poor. But, according to approach to the purplish-brownish zones, I was impressed much by the tropical feature of the fauna and flora. At last I was fascinated completely when I looked into the deep pools, Yato and the water at the reef edge. How many other tropical animals does this sea conceal under the water?

\section{General Feature of the Invertebrate Fauna in the Intertidal Zone of Nakanosima}

Nakanosima is a volcano island. The main peak is Mt. Otake $1030 \mathrm{~m}$ high, a dormant volcano still jetting vapour and sulphurous gas from several spots near the apex (Fig. 5). The coast line of this island is twice and a half as long as that of Takarazima. We could not explore along the whole coast as already mentioned, but only along the coast near Miyazuru from Amadomari to Sii Saki on the south-western coast and the coast near Nanatuyama Ura on the eastern coast.

Western coast.

Large rocks of augite-andesite fill up the whole beach and a narrow raised coral 
reef fringing the coast below the rocky zone may be exposed at low tide in some places. This reef represents the part lower than the purplish zone in Takarazima. The rocky zone is substituted in many places for the part upper than the yellowish zone in Takarazima. Pools and clefts on the reef are comparatively few and are not well developed as in Takarazima. Moreover, there are wide areas covered by sand, the accumulation of which is especially remarkable near Amadomari at the northern part of the surveyed area. Here, the sand is kept tightly on the reef by the complexly

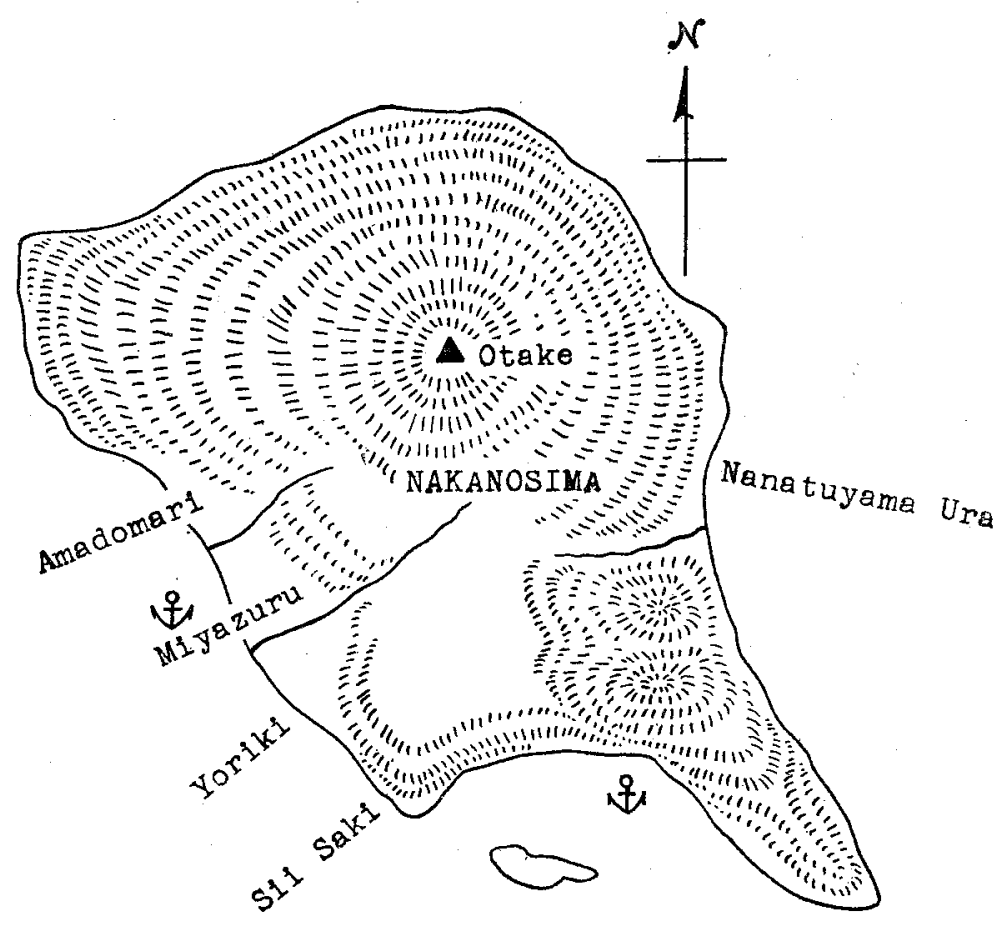

Fig. 5. Map of Nakanosima.

entangling thin nest tubes of a chaetopterid polychaete. In such sandy heaps, we can find sipunculids, enteropneust, small crab Euplax sp., and a cucumariid holothurian Phyllophorus fragilis Mrtsukuri \& OHswima. The fauna on the reef is almost the same as in Takarazima except for the following several features.

1. The surface of the reef is densely crowded by a stellate species of Foraminifera, Baculogypsina sp. (Fig. 6).

2. A compound ascidian, Leptoclinum sp., which harbours zoochlorellae in the lacunae and is coloured blue and green, is commonly found in nearly all shallow pools and on the wall of deep pools.

3. Palythoa and Isaurus are very rare, while alcyonarians such as Sarcophyton 
spp., Clavularia inflata and Lobophytum spp. etc., are much more abundant than in Takarazima.

4. Of the reef corals, Goniastrea aspera is exposed near the reef margin. Besides, only Acropora abrotanoides can be seen along the reef edge at low tide.

5. Ophiocoma scolopendrina is very abundant as in Takarazima, while the living muricids, conids and other snails which are found commonly on the reef of Takarazima are rather scarce. Heterocentrotus mammillatus may be found along the reef margin, but it is extremely rare.

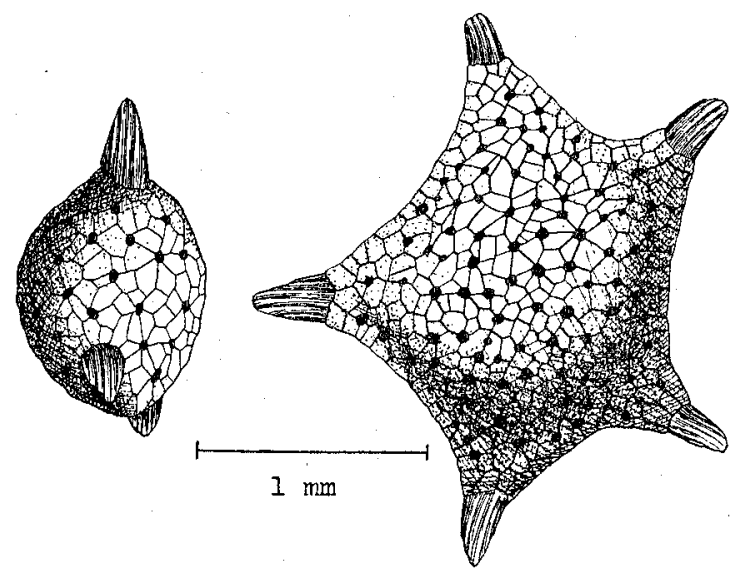

Fig. 6. Baculogypsina sphaerulatus

(PARKER \& JONES).

On the undersurface of stones in pools, we can find easily isognomonid bivalves, Ischnochiton comptus and white or pinkish didemnid ascidians, but no Ascidia aperta which is the common solitary ascidian in Takarazima. The fauna in the rocky zone differs considerably according to places. Probably the existence of the reef or the river may play a significant role. At the anchorage of Miyazuru, the following zones are discernible:

Upper part

$$
\downarrow \quad \begin{aligned}
& \text { Littorinid-zone } \\
& \text { Chthamalus-zone } \\
& \text { Ostrea-zone } \\
& \text { Tetraclita-zore }
\end{aligned}
$$

Lower part

Littorinid-zone consists of chiefly Tectarius (Nodilittorina) vilis (MENKE) and fewer Teciarius (Nodilittorina) granularis GRAY and Littoraria undulata (GRAY), besides a small amount of Littoraria pintado (Wood). Chthamalus-zone consists of Chthamalus 
intertextus and a pulmonate limpet Siphonaria subatra PILsBRY. In the Ostrea-zone, a considerable number of Ostrea (Lopha) cucullata are found mingled with other species. Tetraclita-zone is formed of two subspecies of T. squamosa as in Takarazima, besides Chthamalus pilsbryi HIRo and a small amount of $C h$. malayensis PILSBRY. Some Pedalion acutirostre (DUNKER) are found in crevices on rock and some Cellana toreuma (REEVE) adhere to the surface mingled with barnacles. The rock-slater is very common everywhere in the rocky zone. The nest tubes of Pomatoleios sp. may be found on the surface of rocks which form a part of the purplish zone. Actinia equina (LINNÉ), Mitella mitella (LINNÉ) and a flat barnacle Octomeris brunnea DARWIN are attached to the undersurface of large stones at the level of the Tetraclita-zone and a trochid snail Monodonta (Melagraphia) neritoides (PHILIPPI) is creeping there. Under small stones at this level, we can find a synaptid holothurian Polycheira rufescens (BRANDT), Petrolisthes spp. and a chiton Ischnochiton boninensis FERGENHAYN, besides small crustaceans such as amphipods and Sphaeroma sp. Anthopleura japonica Verrill. and Holothuria (Holothuria) vagabunda SELENKA are found in the water of this level. Some neritid snails migrate up or down the littorinid-zone according to the height of the water and the condition of the surf. Nerita (Theliostyla) exuvia LinNé reaches the highest level beyond the littorinid-zone, next Nerita (Ritena) plicata LiNnÉ reaches the lower part of the littorinid-zond and followed by Nerita (Theliostyla) albicilla LINNE, Nerita (Amphinerita) polita LINNÉ and Nerita (Ritena) undata striata BuRrow, etc. Near the southern village of Yoriki, Littoraria spp. decrease much in the littorinidzone. There are some places where the fresh water always traces under the stones towards the sea. In such places, a zone consisting of Melampus caffer (KüsTER) and Angustasciminea castanea satumana HABE was discovered above the littorinid-zone.

The reef disappears near Sii Saki where the coast is covered by huge rocky stones accumulated from the depths to the foot of the cliff. On these stones, the following zones are distinguishable:

Upper part

\section{Littorinid-zone}

Siphonaria-zone

Chthamalus-zone

Tetraclita-zone

Purplish zone

Brownish zone

Lower part

The littorinid-zone is completely devoid of Littoraria spp. ; Tectarius (Nodilittorina) vilis occupies clearly the upper situation than Tectarius (Nodilittorina) granularis 
which is found merely in a small number. Siphonaria-zone is represented by S. rucuana PILsBry, Chthamalus-zone is represented by $C h$. intertextus and Tetractita-zone contains some Cellana toreuma, Drupa (Morulina) granulata and Thais (Mancinella) distinguenda, etc. The distinction between the purplish and brownish zones is not clear in many places; the former is covered by the nest tubes of Pomatoleios and a purplish Melobesiae, while the latter is clothed with Gelidium divaricatum MARTEns and other small Rhodophyceae, which tend to occur in the submerged zone. A black helmet-shaped sea urchin, Colobocentrotus mertensii BRANDT, can be seen markedly on the purplish surface of the rock near the low water mark.

\section{Eastern coast.}

At Nanatuyama Ura, the sandy beach developes well below the rocky area at the foot of the cliff. The reef is gradually exposed below the sandy shore towards the offing. The upper part of the reef is the yellowish zone, here short and reddish brown Ceramium tenerrimum (MART.) OKAMURA and Centroceras clavulatum (AG.) MoNT. and green Ulva conglobata, all smeard with sand, cover the reef surface. Liagora sp. increases in number in the purplish zone. The fauna of the yellowish zone was very poor, Drupa (Morulina) granulata seemed to be the most important animal at the time of my visit. The general appearance of the zonation observed in Nakanosima is schematically figured in Fig. $3 \mathrm{~B}$ and $\mathrm{C}$.

\section{Rough Comparison between the Intertidal Fauna of Takarazima and That of Nakanosima}

When we compare the intertidal fauna of Takarazima, the southern-most island of the group, with that of Nakanosima, near the northern end of the group, the following two differences may be accepted as important ores. (1) In Nakanosima many animals familiar to us in Kyûsyû and southern Honsyû can be found rather commonly; for instance, Tectarius (Nodilittorina) granularis, Cellana toreuma, Actinia equina and Anthopleura japonica, etc. (2) Palythoa and Goniastrea are not numerous in Nakanosima and merely grown within a short distance from the low water mark. These differences are considered generally to be caused by the differences of the structure of the shore itself. But the second difference, at least, seems to be partly due to the difference of the latitudes of two islands. This consideration does not mean the existence of a remarkable difference of the water climate between the two islands. Probably the difference of the atmospheric climate during the ebb tide limits the range of the distribution of some tropical animals. So far as the littoral water or the water of different currents is not mixed together on a large scale, the change of the hydrological conditicn of "Kurosio" is considered very slight. For instance, the 
purplish zone is retained near the Seto Marine Biological Laboratory in Sirahama below the Ostrea-Tetraclita-zone composed of Ostrea (Saxostrea) echinata QUOY et GAIMARD and Tetraclita squamosa japonica PILSBRY as dominant species, on the coast faced towards the open sea, though it is not so remarkable as in the southern islands. How does the difference of the atmospheric climate affect the intertidal fauna of the islands in "Kurosio"? What correlation can be find between the fauna and the latitude? Where is the boundary, in south from where the intertidal fauna loses violent modification and becomes stable as the tropical one? I hope to continue to gather the material and data in future to prepare some answers against these questions.

\section{Acknowledgments}

I owed much to Dr. H. UTINomI in identifying various corals, alcyonarians and barnacles, to Messis. T. HABE and T. YAMAMOTO for snails and bivalves and to Mr. E. OGATA for sea-weeds. To all these gentlemen I wish to express here my hearty thanks for their kindness. 


\section{EXPLANATION OF PLA'TES IV-VI}

\section{Plate IV}

Plate V

Figs. 1-3. Nakanosima.

Fig. 1. Coast near Miyazuru, with Mt. Otake in its background.

Fig. 2. Coast near Sii Saki.

Fig. 3. Exposed reef near Miyazuru.

Figs. 4-6. Takarazima.

Fig. 4. View of the northern slope near Maégomori.

Fig. 5. Coast near Maégomori.

Fig. 6. A part of the meadow bordered with the thicket of Pandanus-tree, and carpeted by the convolvulus Ipomea Pes-caprae in front.

\section{Plate VI}

Figs. 1 and 2. Parts of the grayish zone in the shore of Takarazima.

Figs. 3 and 4. Parts of the yellowish zone in the shore of Takarazima, showing the sandy pocket-zone (3) and narrow sandy shore (4).

(All photographed by Mr. Osamu Tuzimoto.) 
Publ. Seto Mar. Biol. Lab., III, 2 (1953)

PLATE IV

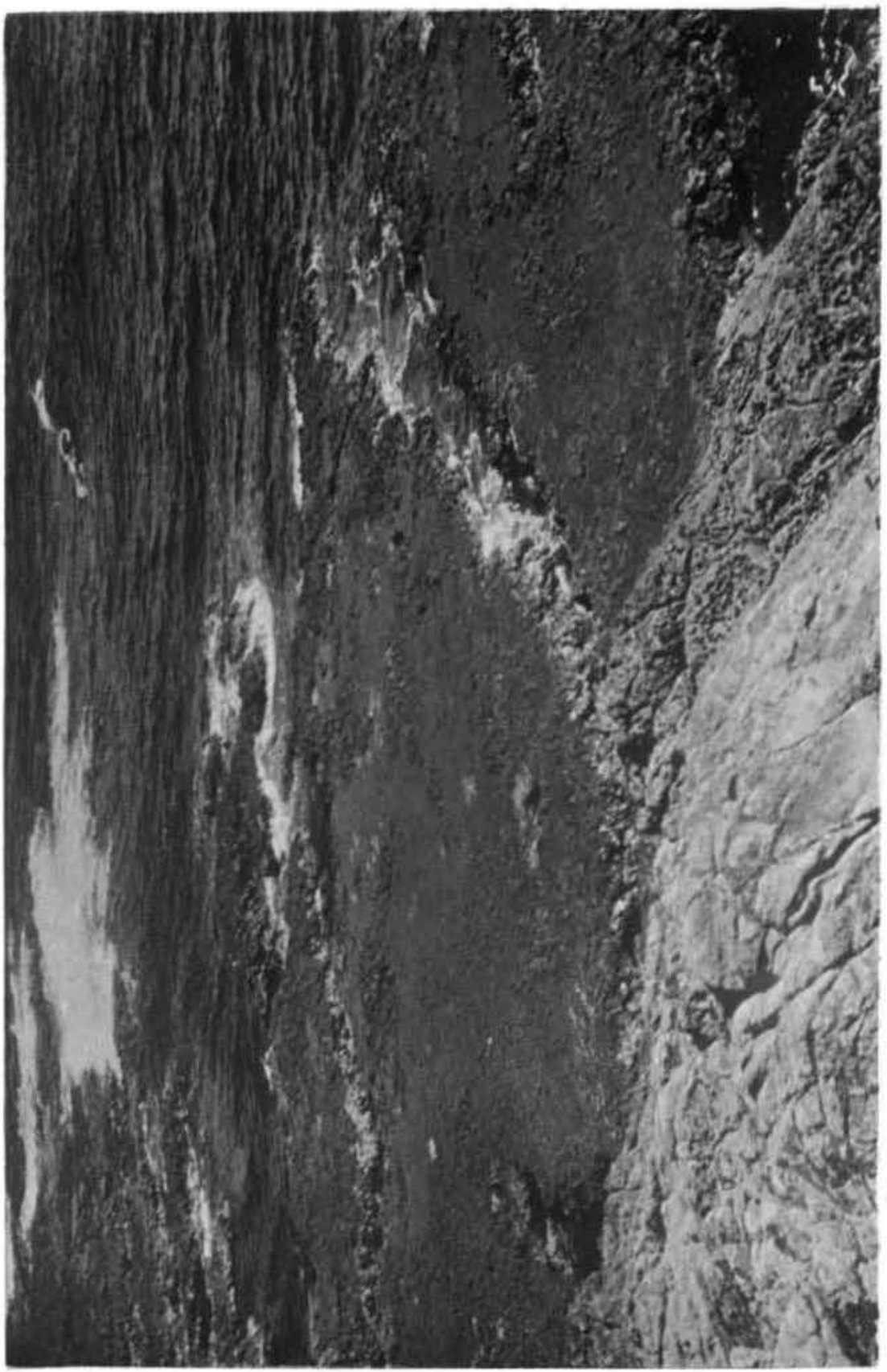

氖

$\geqslant y$

है ธิ

해

둥

ษ

\#告

톤

융을

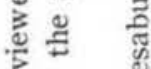

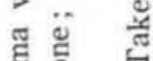

通

氖

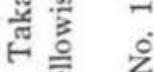

पे

芭 焉

전 녈

8댕ㅎㅀ

वृ का

을 흘

는

단

㟧

흐:

냄으윰

$\varangle$ Q :

Е

T. TOKIOKA: INVERTEBRATE FAUNA OF THE TOKARA ISLANDS, I. 

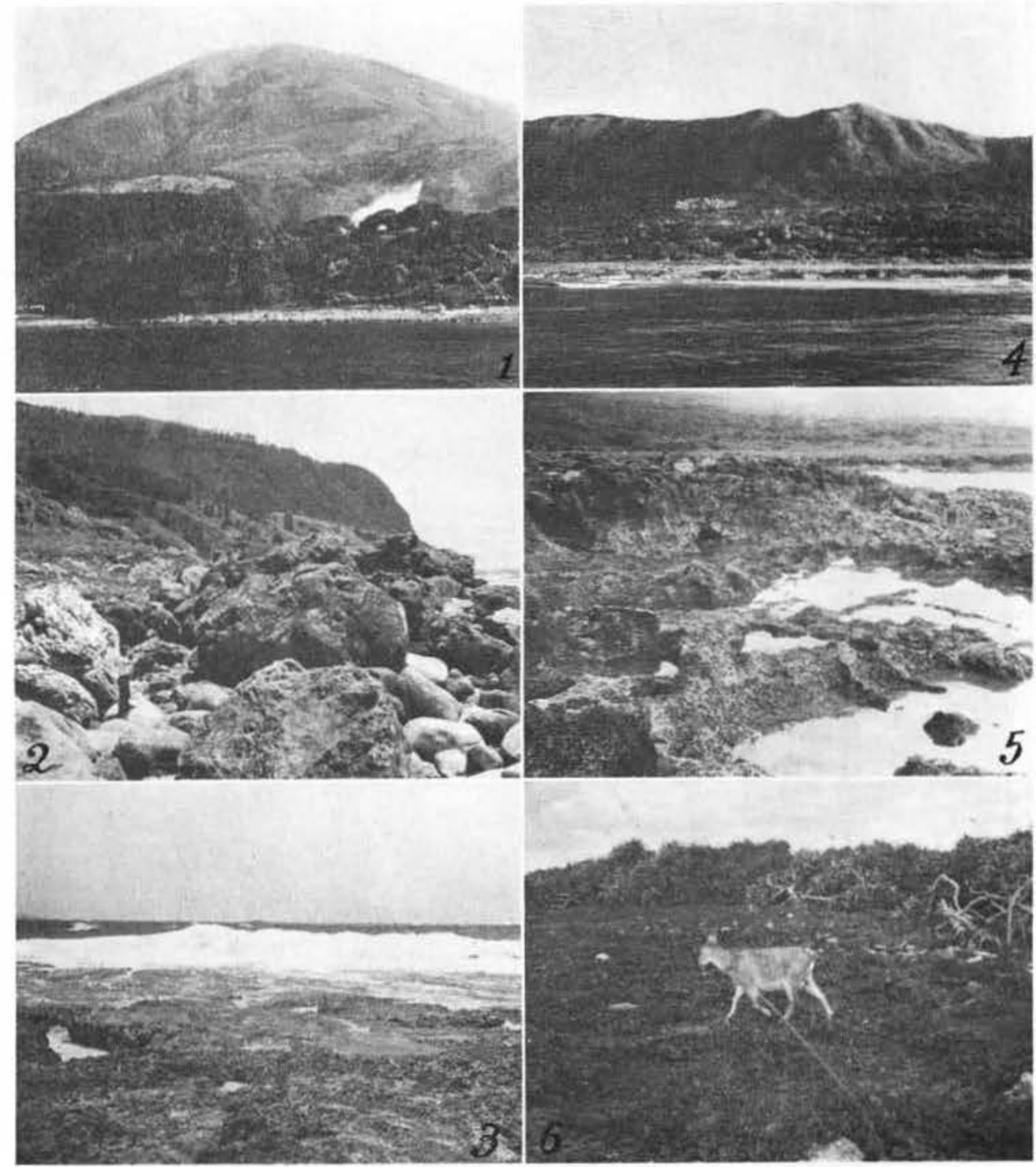

T. TOKIOKA : InVEkTEBrate FAUNA OF THE TOKARA IsL.Ands, I. 
Publ. Seto Mar. Biol. Lab., III, 2 (1953)

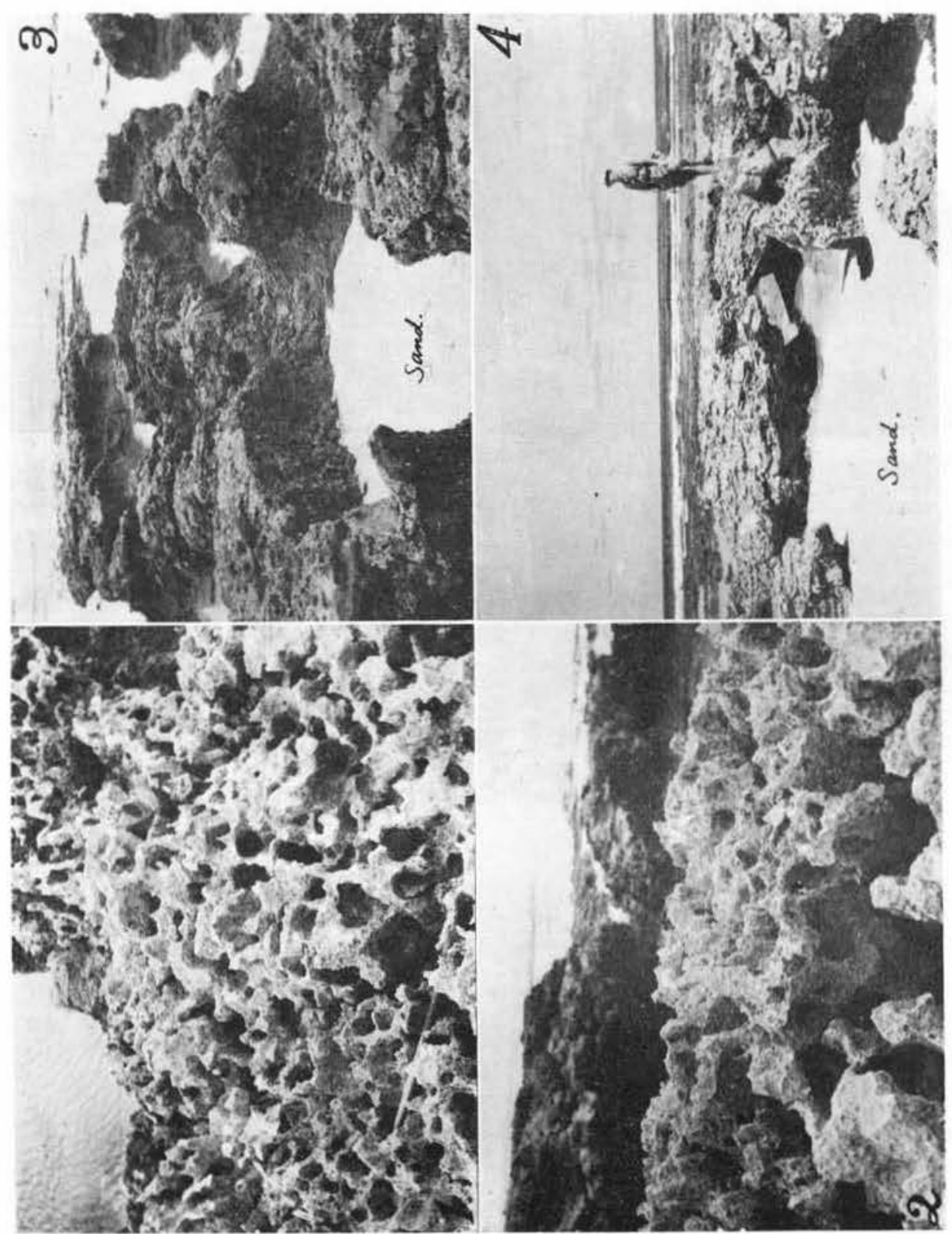

T. TOKIOKA : InVERTEBrate FAUNA OF THE TOKARA IsI.AndS, I. 